\title{
Islamic Wedding Attraction in Entrepreneur Vocational Perspective
}

\author{
Mutimmatul Faidah, Imami Arum Tri Rahayu, \\ Amalia Ruhana \\ Home Economics Department \\ Universitas Negeri Surabaya \\ Surabaya,Indonesia \\ mutimmatulfaidah@unesa.ac.id
}

\author{
Lilik Rakhmawati \\ Islamic Economic \\ UIN Sunan Ampel \\ Surabaya,Indonesia
}

\begin{abstract}
This study aims to describe form and meaning of the Islamic wedding in Lumpur Village. This research is a qualitative descriptive research. The data were collected using interviews, observation, and documentation. The result of this research is Pencak Macan (a wedding ceremony based on Javanese tradition) as the tradition of people from Lumpur Village, Gresik Regency. Pencak Macan shows 4 characters, namely tiger, monkey, warrior, and Genderuwo (a type of genie or spirit which can manifest into human-like apes based on the Javanese myth). The characters in this Pencak Macan tell about many conflicts and problems faced by bride and groom (husband and wife) in the married life. The convoy of warrior in the tradition of Pencak Macan reflects that human being must constantly remember the Almighty God. Islamic values in this show are monotheism, da'wah, justice, knowledge, kinship, aesthetics, and social values.
\end{abstract}

Keywords-wedding, vocational, islamic value, form, meaning

\section{INTRODUCTION}

Gresik was the entry point for Islam to enter Java. It is proven by site (long grave) of Fatimah who is known as the first person to spread Islam in Java. The graves of Malik Ibrahim and Sunan Giri were also found in this city. They are the Wali (Islamic Guardian) to spread Islam in Java. Based on its history, Gresik has been the center of trade and the port town visited by many people from other countries, such as China, Saudi Arabia, Champa (Vietnam), Calcutta, Bengali, and Siam since the $11^{\text {th }}$ century [1]. Gresik is known as the city of santri (Islamic school student) because of the existence of pesantren (Islamic boarding school) and graves of the venerated Islamic guardian (Wali). This historical background livens up multiple events that comprise of the wedding in Gresik. The strategic position as a port town makes Gresik inhabited by people of several ethnics. Most of them live in group in a location inhabited by the same ethnic. Arabian people live in Gapuro and Pulopanikan villages (southern area of the square), Chinese live in Kampung Pecinan (eastern area of square), while Madurese spread around the port [2]. One of villages located around the port is Lumpur Village. This village has a unique tradition in holding the wedding.

Marriage is very important in the life of every person. Marriage is an inner bond between men and women as husband and wife which aims to form a happy family based on the Belief in the One and Only God [3]. In the society, marriage is marked with the marriage contract, formal proposal of marriage (ijab) and acceptance of the proposal (qabul) in front of The One Almighty God, but it is also accompanied by a series of ceremony. Indonesian people recall some sacred events in the circle of human life (life cycle), starting from being a baby in the womb, the birth, marriage, to death. Ceremony and tradition are different in every region.

The difference shows the cultural wealth of Indonesian people since every stage of marriage process has the underlying meaning and philosophical value. Prior studies show that there are meanings at each stage of marriage. In the context of wedding rituals, wedding ceremony such as food serves as an integrating symbol which aims to unite the parties of the bride and the groom, creating a new group of relatives [4]. The presence special food in the Malays wedding ceremony bring a symbolic meaning for the hosts, bridegroom, their family and guests. Symbolizing of fertility, appreciation, sweet life to the bridegroom, blessing, creating strong family bonding, good relationships between guests and marriage declaration are some of the significant on the present those food in the Malay wedding [5]. The Yakut wedding attire represents an important attribute of the wedding ritual. Clothing is described here as an indicator of the bride and groom's social status. The wedding costume describe other significant magic and protective functions [6]. Attributes and attracts in wedding ceremony can be developed to be a Tourism destination. Such Things Need Tourism entrepreneur skills. Vocational education has a role in preparing skilled workers such as tourism business managers and tour guides who understand local culture 


\section{METHOD}

This research specifically studies the form and meaning of the Islamic wedding in Lumpur Village, Gresik Regency. This research is a qualitative descriptive research. The data were collected using interviews, observation, and documentation. The key informants in this research were public figures, humanists, and religionists from Gresik. The data were analyzed with ethno-religion.

\section{RESULT AND DISCUSSION}

\section{A. Form and Meaning of the Islamic Wedding in Lumpur Village, Gresik Regency}

Lumpur Village is one of regions in the northern area of Gresik coastal area. Most of the people are fishermen who catch fish under the sea at night and go home at the morning. The captured fish are sold in a place not far from their houses. The mangroves were around the settlement of fishermen. During high tide, the soil around the fishermen's house is always muddy, so the mud accumulates. Therefore, people name this place "Lumpur" which means the mud. The word "lumpur" is a Javanese language of Gresikan [7].

The origin of this Lumpur Village is inseparable from the legend of Sindujoyo. The legend is written in Babad Kroman. Kyai Sindojoyo is a scholar of Islam whose life approached the perfection, since he was the spirit of scholar of Islam, leader, and humanist in Sindujoyo. He was considered a scholar of Islam since he taught Islam. He was a leader, since he ruled the area named Karang Pasung which covered Lumpur, Kroman, Sikodono, Karangpoh, Tlogopojok, and Roomo. Meanwhile, he was a humanist since his work, Pencak Macan [8], still exists. He embraced Islam, but he still up held the existing tradition.

This village has a unique tradition in holding the wedding, Kirab Manten ceremony. In this ceremony, there is a tradition of Pencak Macan performance. Pencak Macan is an art of procession in wedding, which has been practiced for hundreds years. A number of people wear costumes with characters of warrior, tiger, monkey, and Genderuwo which make the Pencak Macan tradition unique. Pencak Macan performance is only performed when bride and groom are from Lumpur Village, Gresik Regency. Pencak Macan is a part of procession of bride and groom, starting from the house of groom to the house of bride. After the make-up of groom is finished, he will ask for prayer from his parent and get accompanied outside the house. The groom is welcomed by a group of Hadroh Salawat with their unique musical instrument, namely rebana and jidor, followed by the entourage of family and relative from the groom, while bringing a gift from groom to bride, decorated by many colors and beautiful shape.

The entourage of this procession walks to the house of bride, while Pencak Macan is performed on the way until they arrive at the house of bride. Tiger represents the husband, while monkey represents the wife; they get along after a fight caused by the provocation of Genderuwo which represents lust as stated in the song entitled Lir Ilir made by Sunan Giri. Some lyrics from the song are (1) Lir-ilir, Lir-ilir (Get up, get up); (2) Tandure wus sumilir (The plants have bloomed); (3) Tak ijo royo-royo (They are so green); and (4) Tak sengguh temanten anyar (Like new bride and groom). The song tells that bride and groom should get up from the adversity. Getting up from the laziness to increase faith given by Allah the Most Glorified, the Most High in every individual is represented by the plants which start blooming and turning green. The faith must be constantly increased to grow big and be happy, such as the happiness in new bride and groom.

There are four main characters in Pencak Macan, namely warrior, tiger, monkey, and genderuwo. The warrior represents human being as a role model who always invites to virtue and goodness to always increase faith and piety to Allah the Most Glorified, the Most High. This warrior is like awliya who always invites to piety toward Allah the Most Glorified, the Most High. Tiger represents the role of a husband in living a married life like walking in the middle of jungle. Therefore, a husband always has a strong spirit to never give up in living life. This character also represents a strong man with the sense of responsibility toward family. Monkey represents the role of a wife who is agile in taking care of her family and has the pure conscience and honest, noble intention to get married. Genderuwo represents the raging lust when facing several challenges in life in living the married life. The character of Genderuwo is bad in the married life which is triggered by problems in life and worldly temptations.

The characters in this Pencak Macan tell about many conflicts and problems faced by groom and bride (husband and wife) in living the married life. The convoy of warrior in the tradition of Pencak Macan reflects that human being must constantly remember the Almighty God. Husband and wife seldom have egoism, like men or women who pride themselves like tigers. After getting married, bride and groom must act like warrior, invite to goodness each other. The Islamic art of Gresik currently starts to be developed and taught in studio of Lumpur Village. It is held not only for procession in wedding, but also for events in village and other activities of people. The performers in Pencak Macan are all men; they work as fishermen and craftsmen.

Other characters in Pencak Macan are carriers of helmet, umbrella, pontang lima, the Salawat chanter, and carrier of torch. They all have their own symbolization. For example, Pontang Lima is made of banana leaves decorated with young coconut leaves and filled with colorful sticky rice. It symbolizes many sects and groups in Islam, but they have the same purpose, toward The One Almighty God. Torch means that bride and groom can "illuminate" each other or spread Islam. Ketopang is a manggar flower made of papaya decorated by sticks with colorful papers and bamboo to support it. Ketopang is then brought in the process of procession to be torn down and contested by the audiences. In every event, 8 ketopangs are made with one umbrella. Philosophy in choosing or using the number of ketopang and umbrella is the coming of Walisongo in Java to spread Islam 
and give charity and protection to people in Java who were poor at that time. Pontang Lima is a decoration made of banana leaves and made like a boat with decoration of young coconut leaves filled with sticky rise with five colors. There is a cone made of banana leaves in the middle and its top has stick broom and cotton. The implicit philosophy is that new bride and groom must perform pillars of Islam until their death, to get happiness in this world and afterlife [9].

Hadroh is a series of praise for the Prophet with musical instrument, namely rebana and bedug. Hadroh team walks by foot while surrounding the bride and groom by chanting Salawat for Prophet Muhammad (peace be upon him). Hadroh also has philosophy that Islam is the foundation of faith for human being in living life and aims to pray for bride and groom to avoid disaster in living the married life.

\section{B. The Islamic Values of the Islamic Wedding in Lumpur Village, Gresik Regency}

Islam highly dominates all aspects of life in people of Gresik. Historically, the tradition of Pencak Macan is the medium to spread Islam by Kyai Sindujoyo. Fishermen undergo laku tirakat until they get the mandate from their spiritual teacher (Sunan Prapen) to open land in Lumpur Village. Before Islam came, Gresik, including coastal area of Java, was filled with culture of Hinduism and Buddhism. In era of Islam, art of Pencak Macan is a medium made by Kyai Sindujoyo to spread Islam and teach the values of Islam in Gresik. This pattern is almost the same with the teaching of Wali who introduced and taught Islam with wayang (a kind of puppet) [10].

Pencak Macan Ceremony in Lumpur Village, Gresik Regency has the universal noble value. Max Scheler viewed that the value cannot be reduced only as the subjective expression of feeling. The value is immanent in every form. There are four hierarchies of values offered by Scheler, namely spirituality, spiritual, life, and happiness [11]. AlGhazali discussed the main value in the discourse of "etiquette" and bad value in the theme of "al-Afat" [12]. Meanwhile, Ibrahim al-Qissi viewed that Islamic value is the main idealism of purpose, conviction, and rule related to individual behavior and people from Allah the Most Glorified, the Most High. This value limits and provides directions of interaction of human and God, human and himself/herself, human and fellow humans, and human and nature. The existing values in Islam have purpose and facilities for the realization. Al-Qissi elaborated Islamic value into 11 points, namely monotheism, knowledge, da'wah, kinship, law and justice, social, economic, politic, jihad, environmental preservation, and aesthetics values [13]. In this writing, writer refers to the concept of value offered by al-Qissi as the basic in capturing Pencak Macan. Seven values from this show are monotheism, $d a^{\prime} w a h$, justice, knowledge, kinship, and social and aesthetics values.

The value of monotheism which can be learned from this show is monotheism toward God and Prophet. Monotheism toward God is practiced by believing in the only God as the ruler of universe to be worshipped and asked for help. There is no Shirk or intervention of magic power. There is no praise or offering for spirit or the spirit world. Monotheism of Prophet is felt in the hadroh which escorts this event. $D a^{\prime} w a$ h value is seen from the moral message to bride and groom to make religion their guidance in solving every problem in the married life. The aspect of $d a^{\prime} w a h$ to society is also viewed from the capability of this tradition to attract people to see the wedding without invitation. Besides the implicit message in performer, the moral message to be presented by narrator in this art performance becomes the alternative media besides religious speech. Knowledge value can be viewed from the dramaturgy of human life through the fight between good and evil and damage always occurs. The goodness must be fought for at last and will achieve victory. Warrior as the mediator in the fight must give spirit that religion must be the foundation in the married life and society.

Value of justice can be referred to men and women in this art who are equal in the humanity in spite of playing different role. Men who protect their wife and are responsible for facing life are shown in the character of tiger. The agility of women in playing the role to manage household affairs is shown in the character of monkey. The value of aesthetics is revealed in the beauty of art; movement of dance, fashion, make-up, and gamelan which is neatly arranged. The social value is bond to unite villagers. Pencak Macan is not an event for family, but for all villagers. They are responsible for succeeding this event through committee which involves them.

The value of kinship is seen from the togetherness of relative and family in following the procession of Pencak Macan. They follow behind this procession to accompany the groom to the house of bride by bringing the beautifully decorated foods. Some of family and neighbor follow the procession; they make and decorate gift to be brought to house of bride.

This phenomenon of Pencak Macan cannot be separated from the embodiment of culture in the society. Koentjaraningrat explained the embodiment of culture in Cultural Philosophy, Cultural Behavior, and Cultural Artifact [14]. The existence of Pencak Macan is manifestation or embodiment of culture in Gresik. Idea about the married life which will be experienced by bride and groom is inseparable from several motions and attractions in this dance, costume, and attribute. Four characters are manifestation of culture (Cultural philosophy). The fight among Genderuwo, tiger, and monkey which is ended by Warrior is the manifestation of Cultural Behavior. Ornaments, such as costume, ketopang, pontang lima, and umbrella, are the embodiment of cultural artifact. These three embodiments of culture are united in performance of Pencak Macan.

Referring to the phenomenon, Ernst Cassirer, in his book entitled An Essay on Man: An Introduction to a Philosophy of Human Culture, stated the concept about human being as the symbolic animal. This concept implies that human being is differentiated from other creations of God based on their 
capability in creating and understanding symbol [15]. These four characters deliver the symbolic message of various characters of human being in life. Motion in the show of Pencak Macan is also symbolic act in which there is always a fight between right and wrong. Pencak Macan as the cultural product is the manifestation from reflection of way of life and spirituality understanding from society as a cultural entity. The character of Pencak Macan describe sign and symbol of human life [16].

\section{CONCLUSION}

The performance of Pencak Macan as the tradition of people from Lumpur Village, Gresik Regency. Pencak Macan shows 4 characters, namely tiger, monkey, warrior, and Gendoruwo. The characters in this Pencak Macan tell about many conflicts and problems faced by bride and groom (husband and wife) in the married life. The convoy of warrior in the tradition of Pencak Macan reflects that human being must constantly remember the Almighty God. Islamic values in this show are monotheism, da'wah, justice, knowledge, kinship, aesthetics, and social values. This tradition has the opportunity to be packaged into a tourist attraction. This provides opportunities for vocational education in the tourism services business sector

\section{REFERENCE}

[1] P. Gresik, "gresikkab.go.id," Wednesday June 2017. [Online]. Available: http://gresikkab.go.id/profil/sejarah. [Accessed Friday August 2017].

[2] R. Winarni, Cina Pesisir: Jaringan Bisnis Orang-Orang Cina di Pesisir Utara Jawa Timur Sekitar Abad XVIII, Denpasar: Pustaka Larasan, 2009.

[3] K. Agama, "Undang-Undang Perkawinan," Kementrian Agama RI, Jakarta, 1974
[4] T.I. Chudova, "Food symbolism in the context of komi (zyrians) wedding rituals," Archaeology, Ethnology and Anthropology of Eurasia, Vol 39, Issue 3, September 2011, pp. 128-134, 2011.

[5] Rosmaliza Muhammad, Mohd Salehuddin Mohd Zahari, Alina Shuhaida, Muhammad Ramly Roslina Ahmad, "The Roles and Symbolism of Foods in Malay Wedding Ceremony," Procedia - Social and Behavioral Sciences, Vol 29, Issue 2, June 2010, pp. 268-276, 2010.

[6] S.I. Petrova, "Clothing In Yakut Traditional Wedding Rituals (19th20th Centuries)," Archaeology, Ethnology and Anthropology of Eurasia, Vol 38, Issue 2, June 2010, Pages 106-110, 2010.

[7] Loemaksono, Sekelumit Kisah Asal-Usul Nama Desa, Surabaya: Persada, 2014

[8] N. F. Hamidah, "Perkembangan Rumah Toko pada Kampung Pecinan Gresik," AVATARA e-Journal Peniddikan Sejarah, Vols. 3, No 3, no. Pendidikan Sejarah, 2015.

[9] Alfiyah, "Kesenian Pencak Macan di Gresik: Studi tentang Fungsi Kesenian Pencak Macan," UIN Sunan Ampel, Surabaya, 2014.

[10] D. K. Aziz, "Islam dan Akulturasi Budaya Jawa," Fikroh, Vols. Vol I, No 2, Juli - Desember, no. Humaniora, p. 254, 2013.

[11] Scheler, Der Formalismus in der Ethik und die Materiale Wertethik, Gesammelte Werke, Bern: Frenke Verlag, 1966.

[12] al-Ghazali, Ihya Ulumuddin, Beirut: Dar al-Fikr, 2009.

[13] al-Qissi, al-qimah fi al-Islam, Kairo: Dral-Ma'arif, 2012.

[14] Koentjoroningrat, Pengantar Ilmu Antropologi, Jakarta: Rineka Cipta, 2013.

[15] C. Ernest, Manusia dan Kebudayaan, Jakarta: Gramedia, 2009.

[16] S. R. Kurmanova, "Wedding Food of Germans Living in Siberia: Symbols and Signs," Archaeology, Ethnology and Anthropology of Eurasia, Vols. Vol 43, Issue 2, June 2014, no. Ethnology, pp. 126-127, 2014 